\title{
Erratum to: Genetic diversity and population structure of Ascochyta rabiei from the western Iranian Ilam and Kermanshah provinces using MAT and SSR markers
}

\author{
Khoshnood Nourollahi • Mohammad Javannikkhah • Mohammad Reza Naghavi • \\ Judith Lichtenzveig • Sayed Mahmmod Okhovat • Richard P. Oliver • \\ Simon R. Ellwood
}

Published online: 28 July 2010

(C) German Mycological Society and Springer 2010

\section{Erratum to: Mycol Progress}

DOI 10.1007/s11557-010-0668-3

The original version of this article unfortunately contained incorrect author affiliations. The correct information is as follows.

K. Nourollahi

Agricultural College

University of Ilam

Ilam, Iran

K. Nourollahi $\cdot$ M. Javannikkhah $\cdot$ S. M. Okhovat

Plant Protection Department

Agricultural College

University of Tehran

Karaj, Iran

The online version of the original article can be found at http://dx.doi. org/10.1007/s11557-010-0668-3.

K. Nourollahi

Agricultural College, University of Ilam,

Ilam, Iran

K. Nourollahi · M. Javannikkhah · S. M. Okhovat

Plant Protection Department, Agricultural College,

University of Tehran,

Karaj, Iran

\section{R. Naghavi}

Agronomy and Plant Breeding Department, Agricultural College,

University of Tehran,

Karaj, Iran

\section{J. Lichtenzveig $\cdot$ R. P. Oliver $\cdot$ S. R. Ellwood $(\bowtie)$}

Australian Centre for Necrotrophic Fungal Pathogens,

Health Sciences, Murdoch University,

Perth, WA 6150, Australia

e-mail: srellwood@gmail.com
M. R. Naghavi

Agronomy and Plant Breeding Department

Agricultural College

University of Tehran

Karaj, Iran

J. Lichtenzveig · R. P. Oliver · S. R. Ellwood (*)

Australian Centre for Necrotrophic Fungal Pathogens

Health Sciences

Murdoch University

Perth, WA 6150, Australia

Tel: $+61-8 / 9360-1277$

Fax: +61-8/9310-4144

e-mail: srellwood@gmail.com

We apologize for any inconvenience.

The publisher 